\title{
VÝZNAMNÉ KRAJINNÉ PRVKY JAKO MOŽNOST UCHOVÁNÍ PAMĚTI KRAJINY: PŘÍPAD MODŘICE
}

\author{
Pavla Pokorná, Milada Št’astná
}

\begin{abstract}
A significant landscape element represents an environmentally, geomorphologically or aesthetically valuable part of the landscape, which shapes its typical appearance or contributes to the maintenance of its stability. This category of general nature and landscape protection can enable us to protect the segments of the landscape that tell us about its history and thus preserve the memory of the landscape. This article describes the historical development of the Modrice cadastral area reflected in the present landscape and preserved thanks to already registered significant landscape elements and small sacral structures. It also describes parts of the landscape that would be eligible to preserve for future generations. There are not much significant landscape elements in the Czech Republic registered during the recent years, however if we would systematically promote their application to protect the memory of the landscape, the whole idea of their importance would have a new dimension.
\end{abstract}

Keywords: significant landscape element, Modřice, memory of the landscape

\section{Úvod}

Často se při pohledu do krajiny ptáme, proč v určitém území je právě město/les/orná půda, př́padně co zde bylo $\mathrm{v}$ minulosti a $\mathrm{v}$ jaké míre se krajina měnila. Téměř v každé krajině můžeme nalézt stopy minulosti a odraz tisíce let zásahů člověka do krajiny. Za jejich počátek můžeme považovat neolitickou revoluci, tedy období, kdy se lovci a sběrači usídlili a začali obdělávat půdu. Od té doby se tvář krajiny několikrát pozměnila, dostala nové strouhy i kopce a jak prrirovnává Maitland (in Gojda, 2000), stala se palimpsestem, tedy neustále přepisovaným pergamenem. Našim štěstím je, že autor často nebyl dostatečně pečlivý a nepodařilo se mu starou vrstvu dostatečně seškrábat a její zbytky nám zůstaly až do současnosti. Tyto útržky historie se obvykle dají spojit s činností člověka a dokládají nám jeho aktivity v určitém území. Část tváře krajiny nám také zůstala zachována v podobě drobných staveb v krajině, kterými jsou např́íklad studánky, smírčí kř́žže, kříže u cest, boží muka a další. Boží muka byla umístována na křižovatkách cest, hranicích pozemků a nejčastěji na hranicích katastrálních území. Proto jsou pro nás dnes důležitým orientačním bodem v současné krajině i při interpretaci historických map (Dohnalová, 2015). 
Není př́liš možností, jak tyto segmenty v krajině ochránit, tak aby zůstala zachovaná pamět' krajiny i pro prř́ští generace. Nejjednodušší možností legislativně ochránit stopy minulosti v krajině jsou Významné krajinné prvky, které jsou jedním ze základních nástrojů obecné územní ochrany. Jako jeden z mála legislativních nástrojů může ochraňovat segmenty krajiny př́rodě blízké i vytvořené člověkem s různým rozsahem i umístěním. Cílem př́ispěvku je popsat využití institutu Významných krajinných prvků pro ochranu stop minulosti v krajině tak, aby byla zachována pamět' krajiny.

\section{Teoreticko-metodologická východiska}

Př́spěvek se zaměřuje na popsání Významných krajinných prvků ve městě Modřice, především jejich význam pro zachování paměti krajiny. K nalézání krajinných prvků shodných v minulosti i dnes byla využita kniha o historii Modřic od Procházky a Valenty (2001) a rozsáhlá publikace Modřice: dějiny města od kolektivu autorů vedených J. Mitáčkem z roku 2017, které podrobně mapují historii Modřic, a dále jsou využity historické mapy zachycující toto území.

Příspěvek hledá a dává př́íklad nové možnosti ochraně historických struktur v krajině. Jak krajinu zkoumat z historického hlediska a které podklady jsou vhodné popisuje Lipský (1999) v publikaci Sledování změn v kulturní krajině. Lipský a kol. (2011) na př́padové oblasti Novodvorska popisují možná využití institutu Významného krajinného prvku a také různé kategorie registrovaných Významných prvků. Jednou z nich je i skupina kulturně historických prvků.

\section{Významné krajinné prvky}

Významné krajinné prvky (dále též „VKP“) definuje zákon č. 114/1992 o ochraně prŕrody a krajiny jako ,ekologicky, geomorfologicky nebo esteticky hodnotná část krajiny utvář́ jeji typický vzhled nebo přispívá $k$ udrženi její stability. " Tento zákon rozlišuje dva typy VKP:

1. VKP ze zákona, kam patří všechny lesy, rašeliniště, vodní toky, rybníky, jezera, údolní nivy.

2. VKP registrované, kterými můžou být přírodě blízké i kulturní části krajiny. Zákon o ochraně přírody a krajiny zmiňuje např́klad mokřady, stepní trávníky, remízy, trvalé travní plochy, naleziště nerostů a zkamenělin, skalní útvary, plochy porostů sídelních útvarů včetně historických zahrad a parků.

Registrace VKP je upravena Metodickou instrukcí odboru obecné ochrany př́rody a krajiny MŽP. Standardně je registrujícím orgán ochrany prírody (dále též „OOP“) pověřeného obecního úřadu (až na několik výjimek obce se statutem města). Speciálními oblastmi jsou zvláště chráněná území, vojenské újezdy a pozemky důležité pro obranu státu, kde provádí registraci OOP jiného úřadu. 
Důležitou, avšak často nedodržovanou podmínkou registrace je, že nesmí být registrovány tzv. VKP ze zákona.

Každý OOP musí vést seznam registrovaných VKP se základními informacemi. Dalším jeho úkolem je informovat o registraci pořizovateli územně analytických podkladů, nájemce dotčených parcel, územně př́islušný stavební úřad a obec.

Nutnost vedení evidence a informovaní nemají př́íslušné OOP u VKP ze zákona. To je jen jeden z problémů tohoto legislativního nástroje. Tím největším je nevyjasnění jednotlivých pojmů (biotopů), které tento nástroj zaštituje. V zákoně o ochraně př́rody a krajiny pojmy vysvětleny nejsou. Některé jsou vysvětleny $\mathrm{v}$ jiných právních předpisech, avšak to není dostatečné, protože na základě např̀. lesního zákona, kde je les definován jako stromy a keře lesních dřevin, které $\mathrm{v}$ daných podmínkách plní funkci lesa. $\mathrm{Z}$ toho vyplývá, že by měl stejné ochraně podléhat př́rodě blízký les i smrková monokultura na jižní Moravě. Vysvětlení v právním předpisu chybí např. pojmům jezero, rašeliniště a údolní niva, jejich význam najdeme vysvětlený velkým množstvím definic v odborné literatuře, není však zcela jasné, jak mají být chápány v souvislosti s VKP.

\section{Vymezení území}

Práce se zabývá katastrálním územím města Modřice, které leží 7 km jižně od krajského města Brna v Jihomoravském kraji, po obou stranách řeky Svratky. Katastrální území leží v Leichovském bioregionu, který náleží do Dyjskosvarateckého úvalu (Culek, 1995). Geomorfologicky území patří do dvou podcelků: Dyjsko-svratecké nivy a Rajhradské pahorkatiny, jejich hranice prochází středem Modřic od severu $\mathrm{k}$ jihu a viditelně nám odděluje dvě odlišné části modřické krajiny (Bína, Demek, 2012). Rozloha katastrálního území je 1005 ha, k 1. 1.2018 bylo dle Českého statistického úřadu bydlících obyvatel Modřic 5246.

\section{Pamět' krajiny a významné krajinné prvky v Modřicích}

Umístění města Modřice $\mathrm{v}$ blízkosti velké řeky, na úrodných půdách a s rozsáhlým lesem nedaleko, lákalo mnohé skupiny lidí k osídlování. První nalezený doklad osídlení je z doby před 100000 let, další doklady jsou z období lovců mamutů, tedy asi 20000 až 40000 let. Nedaleko modřického náměstí se také nacházelo sídlišstě z mladší doby kamenné a další civilizace (např. římané, keltové) se zde usídlovaly před změnou letopočtu i po něm.

Významnějšími změnami, které ovlivnily krajinu, byla výstavba hradu v první polovině 13 . století, 1517 vybudování rybníku a jeho zrušení na konci 18 . století, 1839 výstavba železnice Brno-Vídeň, regulace toku Svratky v roce 1848, 1880 výstavba cihelny a těžba hlíny, odsun německých obyvatel po roce 1945 , od počátku 20. století rozvoj průmyslu a obchodních zón na orné půdě (Procházka, 
Valenta, 2001). Tyto všechny události a mnohé další jsou zapsány do krajiny v okolí obce i jejím okolí.

V celém katastrálním území se nachází pět registrovaných Významných krajinných prvků (obr. 1) a jeden z nich je i Evropsky významnou lokalitou v rámci soustavy Natura 2000. Čtyři z pěti registrovaných VKP ochraňují části krajiny vytvořené člověkem $v$ minulosti, poslední ochraňuje zbytek lesa, který je z poloviny prrírodě blízký a z druhé akátina.

Obr. 1: VKP v katastru Modřic

Figure 9: Significant landscape elements in the cadastral area Modřice

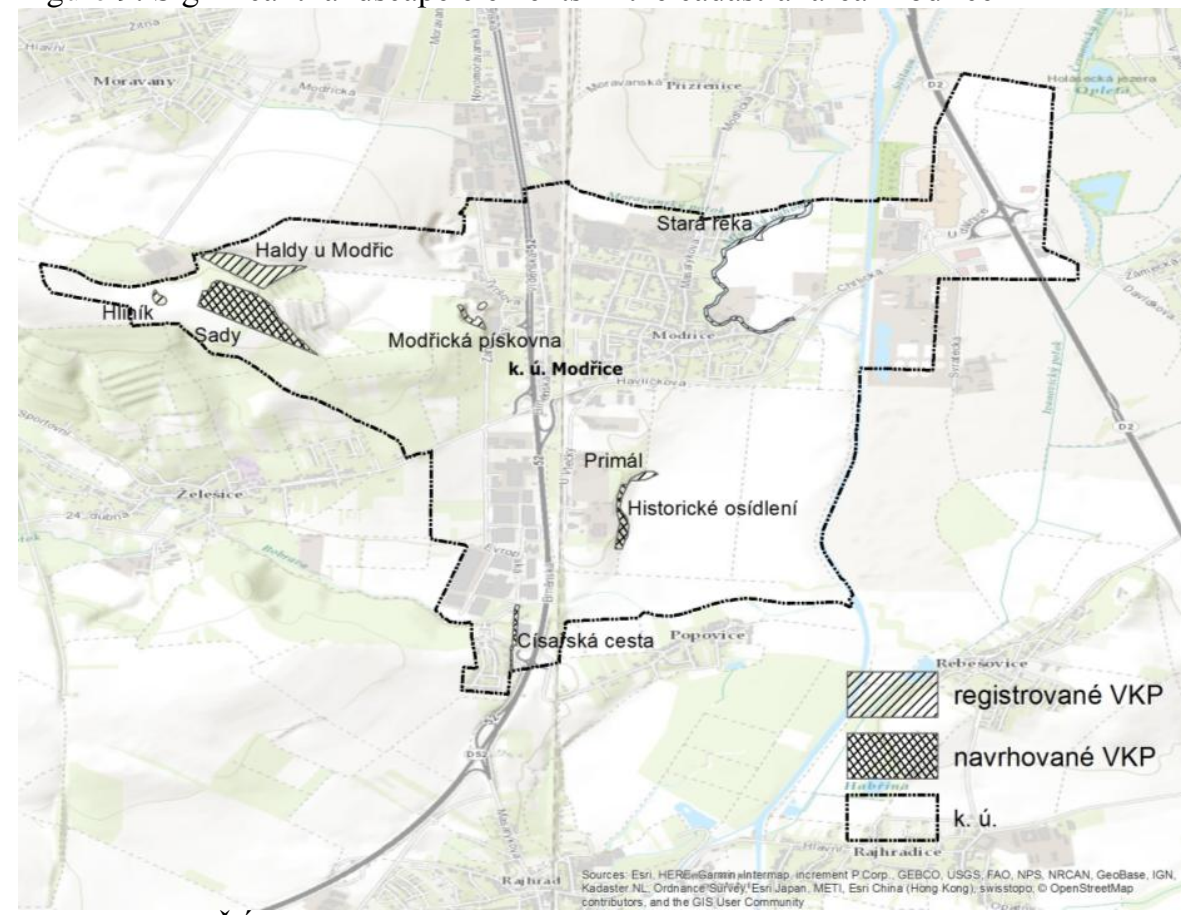

Zdroj: autori, ČÚZK

VKP Haldy u Modřic: Nejrozsáhlejší les v katastrálním území Modřic, specifické hadcové podloží a teplé podnebí umožňuje růst chráněných rostlin jako je lilie zlatohlavá (Lilium martagon L.) a hořeček brvitý (Gentianopsis ciliata (L.) Ma). Les je v této lokalitě poprvé patrný na mapě stabilního katastru z roku 1825 . Na mapě I. vojenského mapování z období 1764-1768 je v této lokalitě orná půda a zobrazen je pouze les v těsné blízkosti na katastru Moravan (obr. 2). 
Obr. 2: VKP Haldy u Modřic v roce 1953 a dnes

Figure 10: Significant landscape element Haldy in 1953 and now
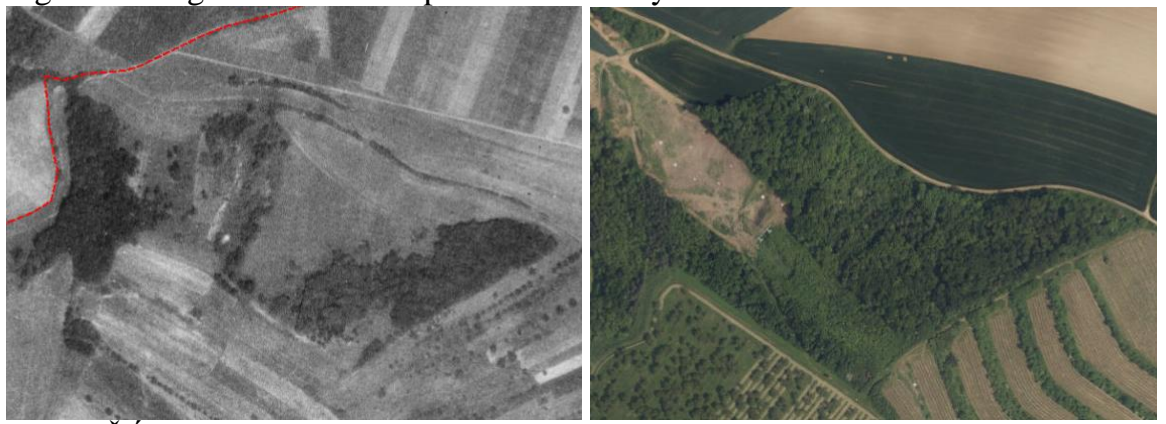

Zdroj: Č́́ZZK

VKP Hliník: Z leteckých snímků lze vidět pouze lesnatý výběžek do orné půdy o rozloze $0,6 \mathrm{~km}^{2}$. Pokud se však vstoupí dovnitř, člověk se rázem ocitá v jiném světě. Zalesněná umělá prohlubeň, která vznikla odtěžením hlíny, je dnes útočištěm zvěře. Oproti okolní otevřené krajině je v lokalitě chladněji a díky terénní depresi a stromům je zde během vegetačního období celodenní př́tmí. $\mathrm{Na}$ leteckém snímku z 50. let minulého století (obr. 3) lze vidět počátky těžby a dnešní zalesnění lokality.

Obr. 3: VKP Hliník v 50. letech a dnes

Figure 11: Significant landscape element Hliník in the 1950s and now
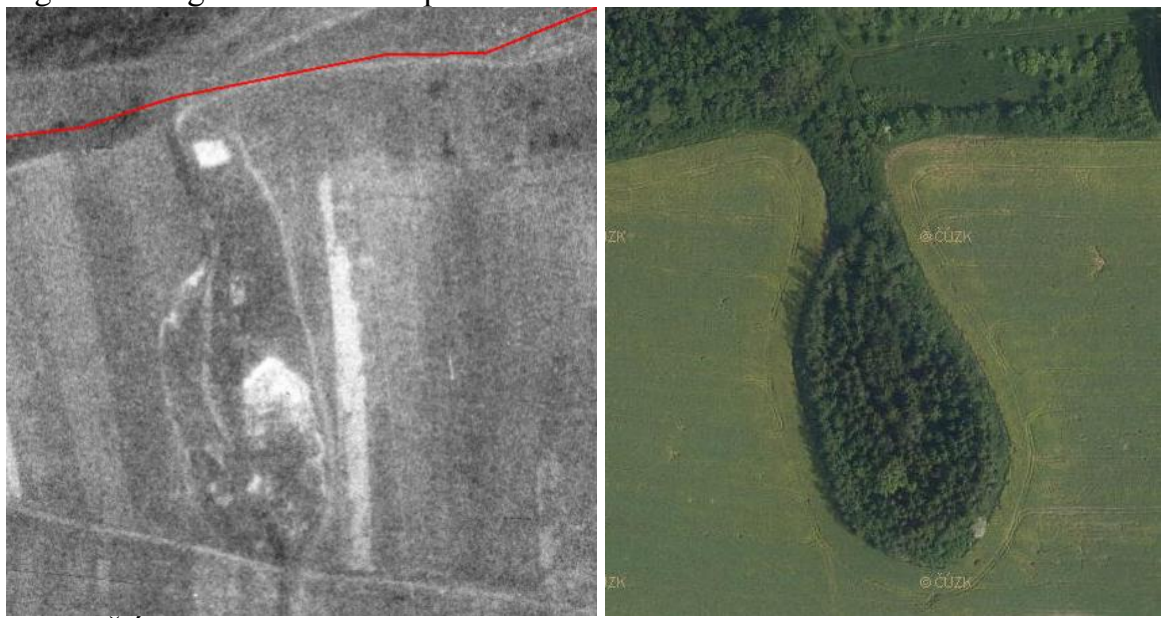

Zdroj: ČUZZK 
VKP Modřická pískovna: Nejhojněji navštěvovaný Významný krajinný prvek ležící v těsné blízkosti výletního areálu Pod Kaštany s barvitou historií (obr. 4). První využití vrcholu ještě před těžbou bylo jako šibeniční vrch a to až do roku 1729, kdy byl hrdelní soud Karlem VI. v Modřicích zrušen (Štarha, 1995). Šibenice je znázorněna na mapách I. vojenského mapování. Blízko vrcholu byla $\mathrm{v}$ roce 1880 vystavěna první cihelna na katastru Modřic a později se $\mathrm{z}$ kopce začala odtěžovat. Vytěžením vzniklý prostor sloužil až do roku 1998 jako skládka komunálního odpadu a podle místní obyvatel i pro místní podnik Fruta. Odpad byl poté překryt tenkou vrstvou zeminy. V současnosti slouží areál jako místo pro pořádání kulturních a sportovních akcí. Každoročně se „Pískáč“ (jak se prostoru dnes ř́iká) proměňuje ve středověké ležení a je dějišš̌m historické bitvy. Jedním $\mathrm{z}$ důvodů registrace VKP bylo hnízdění břehulí ríčních (Riparia riparia L.), ty se již několik let do lokality nevracejí z důvodu zarůstání kolmých stěn těžebního prostoru (Procházka, Valenta, 2001).

Obr. 4: Stav těžebního prostoru v roce 1953 a v současnosti

Figure 12: Condition of mining space in 1953 and present
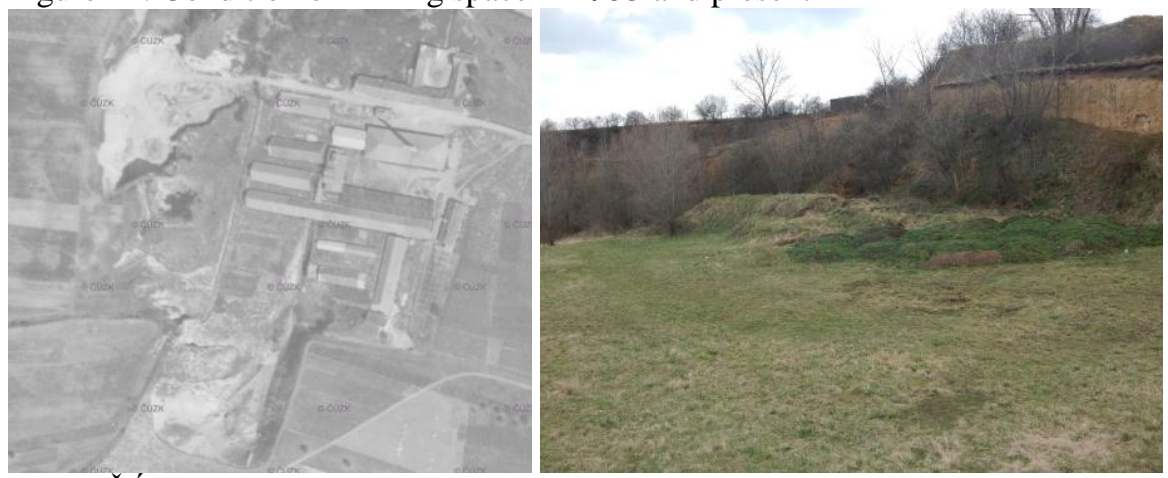

Zdroj: ČÚZK, autori

VKP Stará řeka: Tento krajinný segment nejnázorněji vypovídá o historii krajiny. Je to místo, pro které existuje několik jmen (obr. 5), avšak důležité je, že se i díky registraci VKP a později vyhlášení evropsky významné lokality podařilo zachovat alespoň část původního koryta řeky Svratky. Na toku leží i jediný vodní mlýn v katastru, jehož obyvatelé se o VKP starají, zároveň jejich rodina vlastní nejvíce zemědělské půdy v katastru a svojí činností ovlivňují podobu krajiny. 
Obr. 5: Schématický plánek VKP Stará řeka

Figure 13: Schamatic plan of significant landscape element Stará řeka

k. ú. Přízřenice

k. ú. Modřice

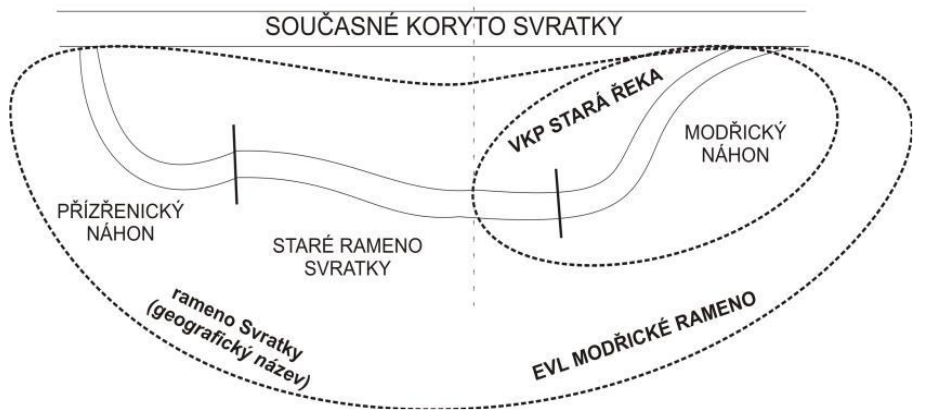

Zdroj: autori

VKP Primál: Současná rozloha rybníku, který je hlavním důvodem registrace, je pouze pozůstatkem jeho původní velikosti (obr. 6). Rybník byl původně přibližně dvacetkrát větší a nechali ho zbudovat měšt’ané jako způsob př́ijmu do městské pokladny. Vybudován byl v roce 1517 a již v roce 1518 do něj chodili lidé z nedalekých Popovic prát a napájet zvěř (Procházka, Valenta, 2001). V průběhu 17. a počátku 18. století rybník pustnul a byl průběžně zúrodňován na drobná políčka a zahrady. V roce 1759 biskup Leopold Bedřich rozhodl o obnovení rybníka i přes odpor místních domkařů, jeho stav po obnovení můžeme vidět na mapě 1. vojenského mapování (Mitáček, Procházka, 2017). Plocha bývalého rybníka je v současnosti meliorovaná a je využívaná jako orná půda. V nejbližší době se krajina $\mathrm{v}$ těchto místech opět promění podle plánu protipovodňových opatření, sníží se břehy Svratky, vytvoří se zelené průlehy a rozšírí se zeleň v okolí toku, vše pak bude sloužit jako rozlivná plocha při povodních.

Všechny registrované VKP zachycují některé období vývoje katastru obce. Zbývá však několik segmentů krajiny, které vypovídají o historii, avšak ještě nejsou nijak chráněny. Je to např́klad pozůstatek císařské silnice na Vídeň s lipovou alejí v části města nazývané Bobrava (obr. 7). $Z$ aleje zbývají převážně jen torza. V ulici i jejím přilehlém okolí přibývá obytné zástavby i průmyslových objektů, $\mathrm{z}$ toho důvodu se uvažuje o rozšiŕení silnice a tím úplnému zániku aleje $\mathrm{i}$ nemožnosti jejího obnovení.

Dalším segmentem jsou sady na vrcholu Vajdl v blízkosti VKP Haldy a Hliník (obr. 8). Tyto převážně meruňkové a broskvové sady jsou patrné již na mapách prvního vojenského mapování. Tento vrchol je i jediným kopcem v katastru a sady a les jasně utvářejí krajinný ráz Modřic. 
Obr. 6: Rybník Primál v 18. století a v letech 1949 a 2016

Figure 14: Pond Primal in the 18th century and in 1949 and 2016

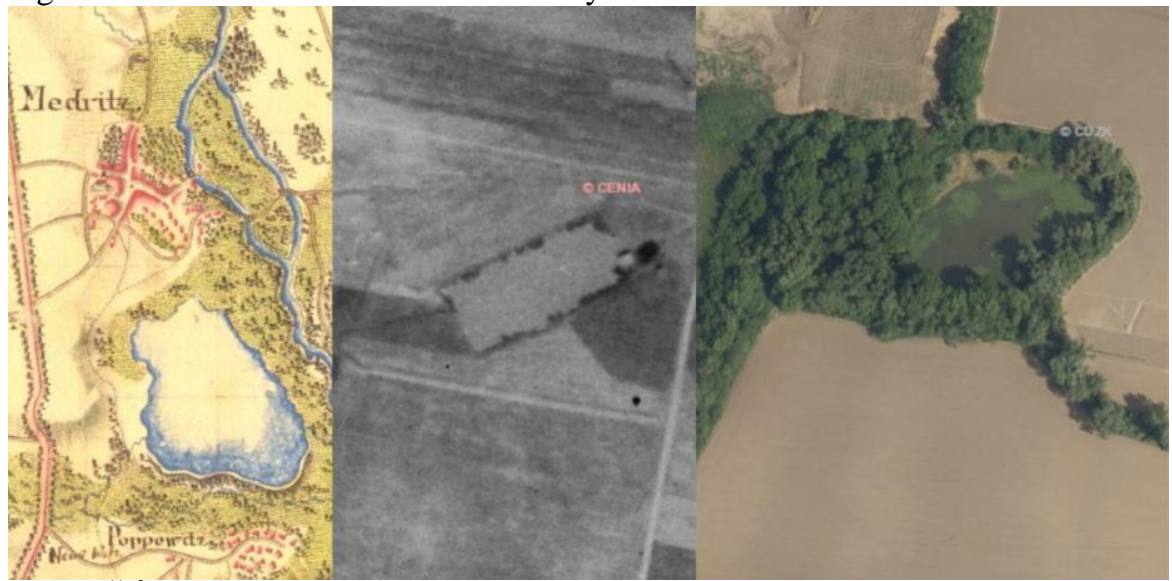

Zdroj: ČÚZK, http://oldmaps.geolab.cz

Obr. 7: Lipová alej v 19. století a letech 1949 a 2017

Figure 15: Alley in the 19th century and 1949 and 2017

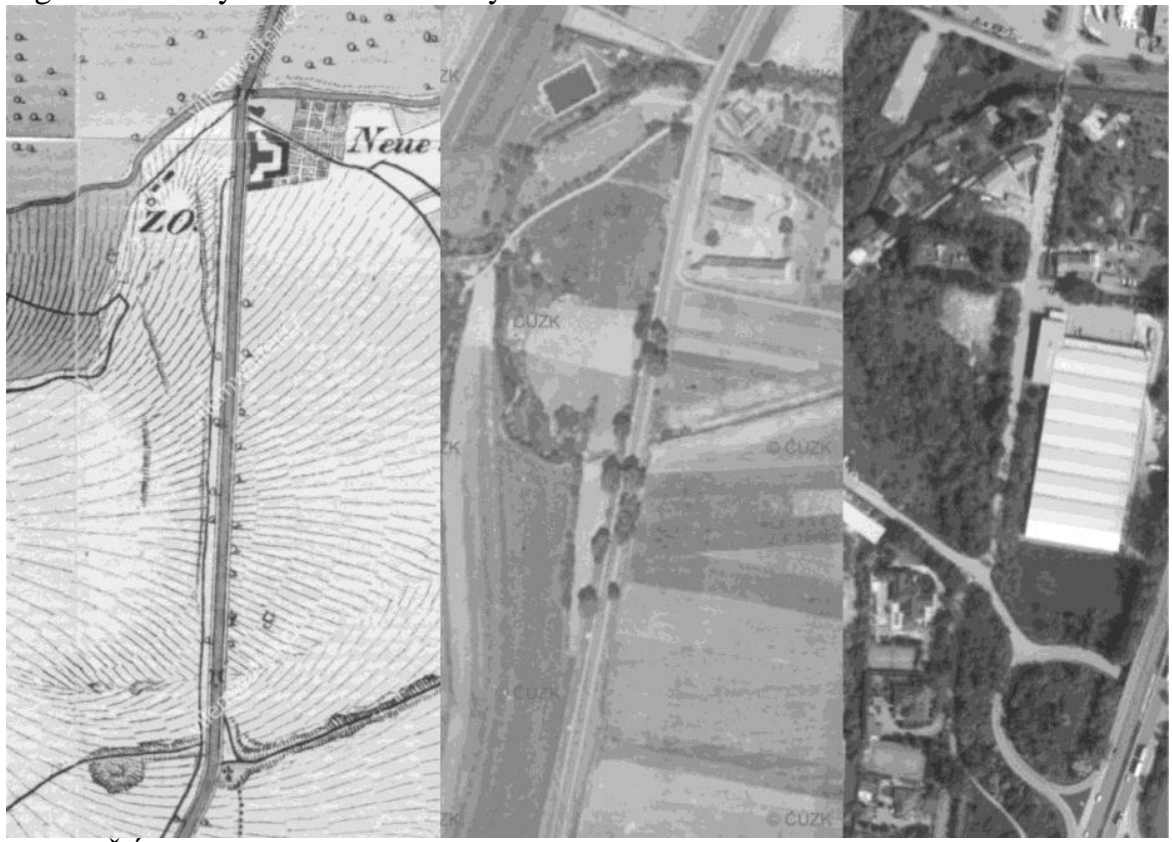

Zdroj: ČÚZK, http://vilemwalter.cz/ 
Obr. 8: Sady v 18. století a dnes

Figure 16: Orchads in the 18th century and today

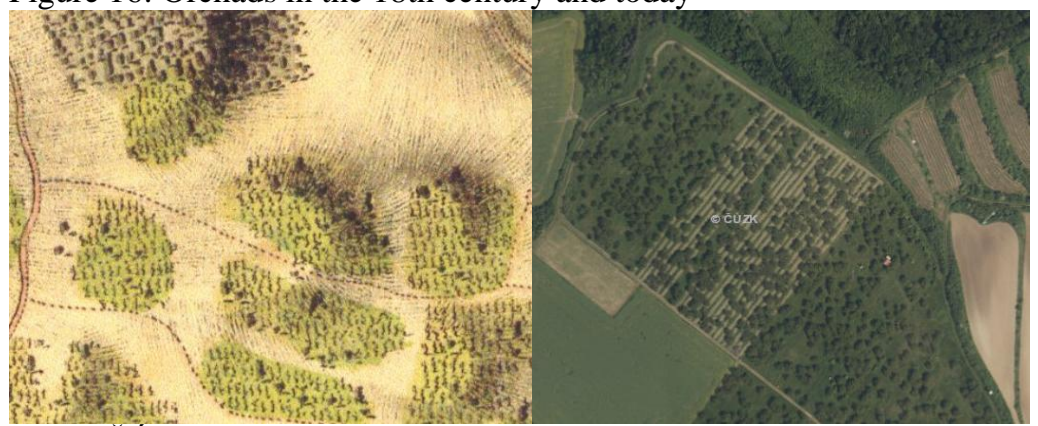

Zdroj: ČÚZK, http://oldmaps.geolab.cz

Třetí lokalitou, kterou by bylo vhodné ochránit, je archeologické naleziště v lokalitě u Vlečky (obr. 9), kde je několik vrstev nálezů a také jsou zde historicky zahrady, které jsou sice dnes opuštěné, ale byla by škoda, kdyby i toto území bylo zastavěno logistickými či výrobními centry. Nejrozsáhlejší archeologický výzkum zde probíhal v roce 2015 jako záchranný před výstavbou jedné z průmyslových hal. V rámci výzkum o rozloze 8,3 ha byly nalezeny objekty od Neolitu až do 11 . století (Kos, Parma, 2015)

Obr. 9: Lokalita "Historické osídlení" v letech 1949, 1953, 2001, 2017

Figure 17: Location "Historical settlements" in 1949, 1953, 2001, 2017

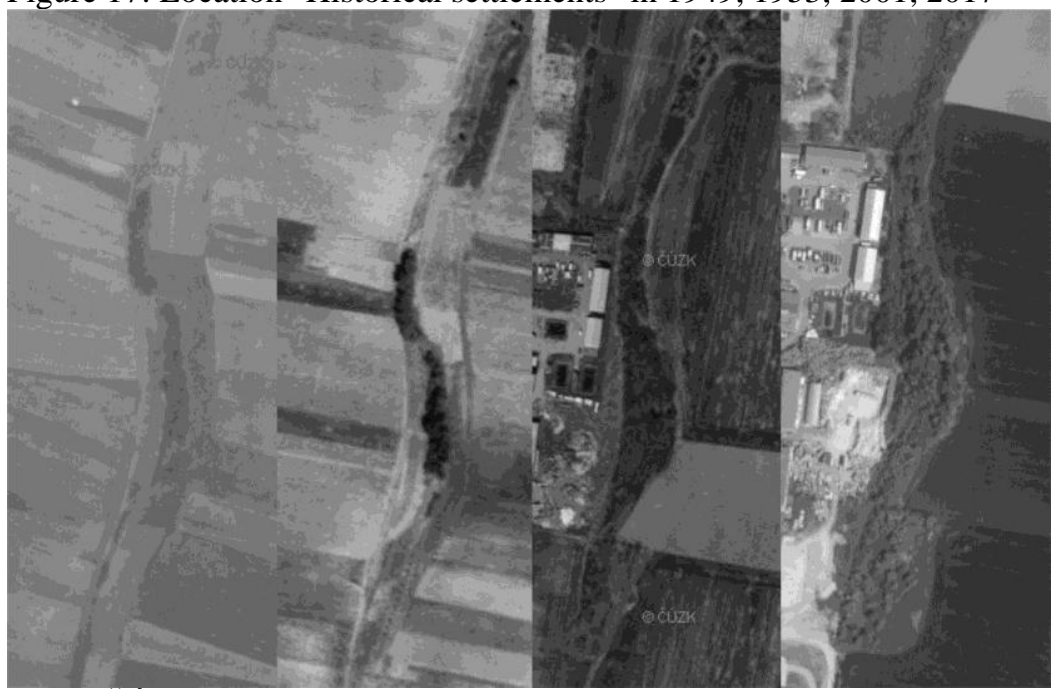

Zdroj: С̌ÚZK 
Velkým problémem Modřic je nedostatečná informovanost o historii obce mezi občany i návštěvníky. Současný starosta je bohužel proti výstavbě naučné stezky či umístění informačních tabulek nejen k VKP, ale i k památkám v zastavěné části obce.

\section{Závěr}

Krajina je kronikou historie naší země. Stejně jako ručně psané kroniky, obrazy i fotografie uchováváme pro př́šśtí generace, bylo by vhodné ochránit i drobné záznamy minulosti uchované $\mathrm{v}$ krajině. Tyto místa většinou nejsou biologicky významná ani nejsou dostatečně rozsáhlá, aby zde byla zřízena Krajinná památková zóna. Potřebujeme však najít způsob, jak je uchránit. Významné krajinné prvky se zdají být vhodným kandidátem na tuto ochranu. Do „významných krajinných prvků ze zákona“ patří území především přírodní, významné části kulturní krajiny, které pak můžeme jako významné krajinné prvky registrovat. Velkou výhodou je možnost navržení této ochrany př́mo majiteli pozemků, občanskými spolky či obcí, a to především proto, že právě tito lidé vědí, která místa jsou pro ně důležitá a jaké př́íběhy se na nich odehrály. Právě pro ně mají tato místa své Genius loci, tedy ducha místa.

$\mathrm{V}$ př́ípadě Modřic jsou některé střípky $\mathrm{z}$ jejich historie již chráněny a některé, třeba i díky úsilí místních, ochranu získají. Právě v tomto případě však bude nejdůležitějším krokem občany (především ty nové) o významnosti jednotlivých míst informovat tak, aby se na historii nezapomínalo, a jasné důkazy historických změn byly vidět i jinde než v učebnicích dějepisu.

Významné krajinné prvky můžou ochránit části krajiny, které bychom jinak ztratili a jinou zákonnou ochranu díky své nezajímavosti, pro jiné než místní, nemůžou získat. V posledních letech se př́liš Významných krajinných prvků v České republice neregistruje, pokud bychom však systematicky prosazovali jejich užívání na ochranu paměti krajiny, získal by celý jejich institut nový rozměr.

\section{Literatura}

BÍNA J. - DEMEK J. 2012. Z nižin do hor Geomorfologické jednotky České republiky. Praha: Academia, 2012. 343 s. ISBN 978-80-200-2026-0.

CULEK, M. 1995. Biogeografické členěni České republiky. Praha: ENIGMA, 1995. 347 s. ISBN 80-85368-80-3.

ČESKÁ REPUBLIKA. 2013. Metodická instrukce odboru obecné ochrany př́rody a krajiny MŽP k registraci významných krajinných prvků. In Věstník MŽP 2013, částka 7, str. 98-113 [online]. 2013. [cit. 2018-09-27]. Dostupné na: <https://www.mzp.cz/cz/metodicka_instrukce_k_vkp>

ČESKÝ ÚŘAD ZEMĚMĚŘICKÝ A KATASTRÁLNÁ (ČÚZK). [online].

Dostupné na: 〈www.cuzk.cz> 
DOHNALOVÁ, B. 2015. Metodika identifikace kulturnich artefaktů v krajinè. Brno: Mendelova univerzita, 2015. s. 21-23. ISBN 978-80-7509-382-0.

GOJDA, M. 2000. Archeologie krajiny: vývoj archetypů kulturni krajiny. Praha: Academia, 2000. s. 59. ISBN 80-200-0780-6.

KOS P. - PARMA D. 2015. Výzkum Modrice, Rybniky - CTP hala MO17. [online]. Dostupné na: 〈https://www.uapp.cz/vyzkumy_15_modrice>

LIPSKÝ, Z. 1999. Sledování změn v kulturní krajině: učební text pro cvičení z předmětu Krajinná ekologie. Kostelec nad Černými lesy: Lesnická práce, 1999. ISBN 80-213-0643-2.

LIPSKÝ, Z. - ŠANTRU゚ČKOVÁ, M. - WEBER, M. 2011. Vývoj krajiny Novodvorska a Žehušicka ve středních Čechách. Praha: Karolinum, 2011. ISBN 978-80-246-1905-7.

MITÁČEK, J. - PROCHÁZKA, R. et al. 2017. Modřice: dějiny města. Modřice: Muzejní a vlastivědná společnost v Brně pro Muzejní spolek Modřice a Město Modřice. Vlastivědná knihovna moravská, 2017. ISBN 978-80-7275-103-7.

PROCHÁZKA R. - VALENTA J. 2001. Modřice 1141 - 2001. Modřice: Město Modřice, 2001. $64 \mathrm{~s}$.

ŠTARHA, I. 1995. Hrdelní soudy v okrese Brno - venkov. In Jižní Morava 31: Vlastivědný sbornik. ISSN 0449-0436, 1995, roč. 31, s. 43-49.

ZÁKON č. 114/1992 Sb. o ochraně prírody a krajiny. In Sbírka zákonů 25. 3. 1992. Ćástka 28. s. 666-692.

\section{SIGNIFICANT LANDSCAPE ELEMENT SUCH AS THE PRESERVATION OF MEMORY OF THE LANDSCAPE: CASE STUDY MODŘICE}

\section{Summary}

Landscape is a chronicle of the history of our country. Just as handwritten chronicles, pictures and photographs are kept for future generations, it would be advisable to protect small records of the past kept in the landscape. These sites are usually not biologically significant or large enough to achieve a protection status "Landscape Conservation Area". Therefore, we need to find a way how to protect them. "Significant landscape elements" seem to be a suitable solution for such protection. The " significant landscape elements based on the law" include the area of primarily natural, significant part of the cultural landscape which can be registered as significant landscape elements. The significant advantage here is the possibility of proposition of the protection status directly to landowners, civil societies or municipalities, especially because these people know what places are important to them and what stories lies behind them. Especially for them, these places have their Genius loci - the spirit of the place.

Modřice is a small town located south of Brno, which has no significant natural values, and modern buildings replaced the site of the episcopal castle. Still, 
we can find places in the countryside that tell stories. Some of them are already registered significant landscape elements. The reason for the enlistment is often the most important plants or animal's appearance in the locality. Such an example may be the story of the significant landscape element called Modřická pískovna, where at first gallows was standing, later on a brick raw material was mined, replacing the household waste and the local company Fruta, which subsequently moved in. Due to the overflowing vegetation the sand martins appeared and soon left, battle and other cultural events. There is also a beautiful view and family houses would be easily sold here. Thanks to the legal protection it is not possible. Similarly, it would be desirable to protect for example the remains of dwellings of previous cultures in the western part of the cadastre, the remnants of the linden alley at the former imperial road in the town of Bobrava and the old orchards on the Vajdl hill, which gradually disappear.

Of course, the memory of the landscape is evidenced also by the small sacral structures on the border of the cadastral territory and the road network, which has not changed much. Anyway, significant landscape elements can protect parts of the landscape that we would otherwise lose as there is no other legal protection for local people. There are not much significant landscape elements in the Czech Republic registered during the recent years, however if we would systematically promote their application to protect the memory of the landscape, the whole idea of their importance would have a new dimension.

\section{Ing. Pavla Pokorná}

Mendelova univerzita v Brně

Zemědělská 1, 61300 Brno

E-mail: pavla.pokorna@mendelu.cz

Prof. Ing. Dr. Milada Št’astná

Mendelova univerzita $v$ Brně

Zemědělská 1, 61300 Brno

E-mail: milada.stastna@mendelu.cz 